\title{
Improvement of organizational and methodological aspects of financial budgeting on agricultural farms
}

\author{
$U$ Urmanova $^{1, *}, G$ Tursunkulova ${ }^{1}, Z$ Bozorboeva ${ }^{1}$, and $A$ Boltaev $^{1}$ \\ ${ }^{1}$ Tashkent State Agrarian University, University str., 2, Tashkent province, 100140 Uzbekistan
}

\begin{abstract}
This article examines the importance and organizational and methodological aspects of financial budgeting on farms. The main, organizational and methodological aspects and main directions of budgeting in farms are shown. Stages of formation of the financial budgeting system, model budgeting model for farms operating in various sectors and stages of financial budgets have been developed, relevant conclusions have been formed, proposals and recommendations have been developed.
\end{abstract}

\section{Introduction}

Proper organization of activities on the basis of well-developed budgets plays an important role in maintaining strict economy, increasing the volume and improving the quality of products in agricultural enterprises, especially on farms [1]. In addition to state support for the activities of farms, it requires ensuring their economic independence, rational use of intellectual, material, labor and financial resources, quality development of financial budgets, improvement of income generation and financing systems [1, 2].

In order to fulfill these tasks and increase the efficiency of farms, first of all, it is necessary to develop sound and quality budgets. In the economic literature, there are different tariffs, approaches and considerations that are close in content to the concepts of budget and budgeting $[3,5]$. The explanatory dictionary of the Uzbek language describes the etymological and lexical meaning of the term budget: However, this commentary does not adequately explain the economic nature, composition, functions and stage of formation of the budget, as well as its role in management decisions [3-5].

In the National Encyclopedia of Uzbekistan, the concept of budget is expressed in almost the same sense as the above definition: The budget can be formed at the state level, as well as at the level of regions, districts, businesses, families or individuals [3]. The difference is reflected in the levels at which the budget is structured $[6,7]$.

The word "budget" is derived from the ancient Norman language and means "bougette" - a bag, a purse, a leather bag, a bag full of money [4, 8]. According to foreign experts B. Needles, M. Powers, S. Mills and G. Anderson, "the budget is an action plan that predicts future economic operations, economic activity and results in terms of financial and non-

* Corresponding author: abror abc@,mail.ru 
financial indicators" [5]. According to economists A.X. Pardaev and Z.A. Pardaeva, "the budget is a financial document that is prepared before the implementation of the planned activities" [6].

The development of a budgeting system on farms or the improvement of the existing system will allow them to increase the level of validity of decisions made in order to improve their financial situation and financial and economic performance, to develop their initial planning for comprehensive planning, financial analysis and financial management. Such decisions include the selection of suppliers and buyers of goods, the increase and distribution of profits, the acceptance of this or that order, the formation of prices, the attraction of credit and debt, the increase in production. All of these are necessary measures that require careful analysis, optimal ratios, and reasonable budgeting [1-4]. The introduction of budgeting will allow more efficient use of resources and assets at their disposal, as well as increase the responsibility of various sectors (crop, livestock, etc.) for the resources and assets at their disposal.

The purpose of budgeting is to rationally organize the distribution of resources by key areas and projects and periods, to ensure the flexibility and austerity of financial resources, to conduct regular financial monitoring and to adapt to changing market demand.

There are also different approaches to budgeting by economists. In particular, according to economists B.A. Khasanov and A.A. Hashimov: "Budgeting is the planning of financial and economic activities of the enterprise for a certain period" [7].

The importance of budgeting is reflected in: "planning and management decisions; assessment of all aspects of the company's financial stability; strengthening financial discipline by the organizational structures of the enterprise; continuous monitoring of the efficiency of individual economic activities and structural units; constant monitoring of changes in the company's financial position" [8-10].

\section{Main text}

As part of the implementation of the budgeting system on farms, the tasks of defining the responsibilities, obligations and interests of each farmer for the competitiveness of the farm are solved. All this is done in conjunction with the improvement of coordination, organization and control of financial results of the farm, financial budgeting and initiative, management development. This requires the prevention of red tape, excessive restrictions and budget inflexibility. These are especially dangerous for small farms and ranchers.

The budgeting system should also include management technology. Therefore, it is necessary to consider the use of methodological, organizational and advanced information technologies to implement it (Table 1).

Table 1. Main aspects of budgeting the activities of farms.

\begin{tabular}{|c|c|}
\hline Main aspects & Clarification \\
\hline $\begin{array}{c}\text { Methodological aspects } \\
\text { of budgeting }\end{array}$ & $\begin{array}{r}\text { Financial budgeting tools (types and forms of budgets, indicators and } \\
\text { normative system), budgeting methods }\end{array}$ \\
\hline $\begin{array}{c}\text { Organizational aspects } \\
\text { of budgeting }\end{array}$ & $\begin{array}{c}\text { Financial structure of farms (objects of budgeting), budget } \\
\text { regulations and mechanisms of budgetary control, division of } \\
\text { responsibilities, system of internal normative documents (regulations, } \\
\text { job descriptions, and others) }\end{array}$ \\
\hline $\begin{array}{c}\text { Introduction of new } \\
\text { information technologies }\end{array}$ & $\begin{array}{c}\text { Compilation of financial forecasts (including scenario analysis, } \\
\text { various options of calculations on the financial condition of the } \\
\text { enterprise and individual types of business), comprehensive } \\
\text { management accounting (by individual types of activities, industries } \\
\text { or divisions, by types of products, by individual contracts) }\end{array}$ \\
\hline
\end{tabular}


The process of financial budgeting on large specialized farms requires a different, separate approach than on small farms and dehkan farms.

Large farms have several internal economic units, industries (agriculture, animal husbandry, etc.), produce a variety of products and purchase material assets, have a large number of employees and seasonal hired workers. Therefore, the formation of financial responsibility centers, the distribution of responsibilities and the appointment of responsible persons, the structure of the document flow schedule (payment, amendments to budgets, etc.), the organization of the process of preparation, formation, coordination, approval, control of budgets, regulation The development of documentation and other organizational measures are key aspects of the financial budgeting process in large diversified farms.

For large farms, the issues of organizational, methodological and information support are crucial in the whole budgeting process, and show that the effectiveness of economic activity depends on the quality of the budgeting process.

Small farms and dehkan farms, by contrast, have a much simpler organizational structure, they are more fluid, and the small number of employees allows them to create a more effective incentive mechanism. From the point of view of the organization of financial budgeting, farms do not require measures for large-scale restructuring and the introduction of a planning system. In this case, it is advisable to use a set of methods of financial budgeting and analysis in order to expand the capabilities of financial management and increase the efficiency of agribusiness management.

Thus, financial budgeting on farms is based on the costs of its introduction and the benefits to be seen. It is expedient that the system of financial budgeting formed on farms consists of two interrelated sections (Fig. 1):

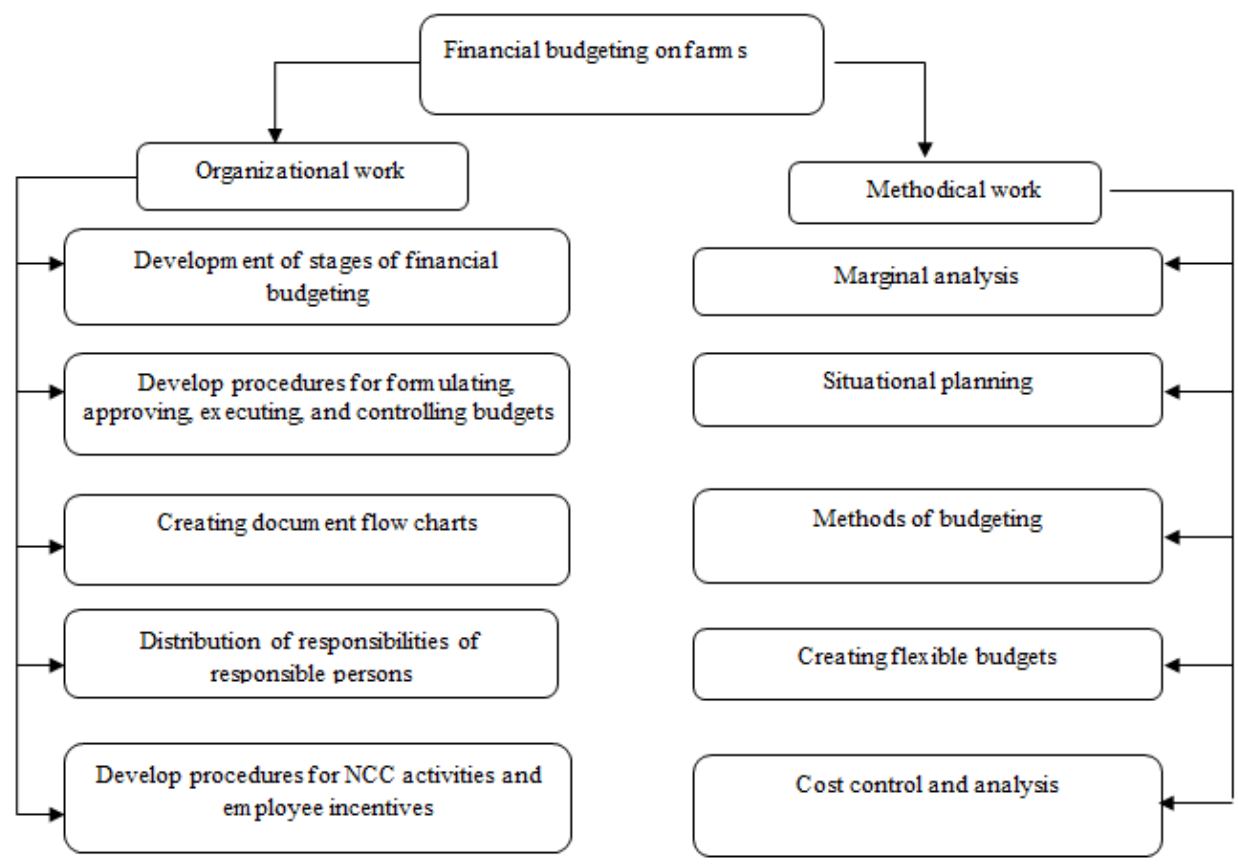

Fig. 1. Organizational and methodological aspects of the development of financial budgets on farms.

1. Development of stages of introduction of financial budgeting system of the department of organizational work, the order of formation, approval and execution of budgets, control of budget execution, formation of the necessary documents and the 
schedule of document flow, distribution of responsibilities of participants of budgeting process, responsibility centers and staff incentives consists of. It does not take much time to develop the procedures included in this section. However, many of them are not present at all in farm practice.

2. The Department of Methodology includes financial budgeting tools, budgeting methods, financial analysis and budgeting methods relevant to agribusiness (marginal analysis, situational planning, flexible budgeting, cash flow management, cost analysis and control, etc.).

The main directions of development and formation of the system of financial budgeting on farms should include: development of strategic goals, definition of goals and objectives of financial budgeting, budgeting, planning and methods of development and implementation of accounting for possible deviations (Table 2).

First of all, it is necessary to define the strategic goals of the farm and formulate tasks to achieve them. The development of budgets is based on the strategic plan of farm development, the target indicators of which should be coordinated (linked) with the current plans.

Table 2. Main directions of financial budgeting on farms.

\begin{tabular}{|c|c|}
\hline Main directions & Meaning \\
\hline $\begin{array}{l}\text { Formulation of financial } \\
\text { strategy }\end{array}$ & $\begin{array}{l}\text { formulating strategic directions of income and expenses and } \\
\text { developing a marketing strategy }\end{array}$ \\
\hline $\begin{array}{l}\text { Defining the goals and } \\
\text { objectives of financial } \\
\text { budgeting }\end{array}$ & $\begin{array}{c}\text { development of key performance indicators, identification of ways to } \\
\text { increase profits, optimization of capital structure, ensuring financial } \\
\text { stability }\end{array}$ \\
\hline $\begin{array}{l}\text { Development and } \\
\text { implementation of } \\
\text { budgeting system methods }\end{array}$ & $\begin{array}{c}\text { - analysis of existing business processes; } \\
\text { - formation of the budget model and budget structure; } \\
\text { - preparation of the general budget; } \\
\text { - accounting and control of economic transactions; } \\
\text { - formation of internal management reports and analysis of } \\
\text { implementation of plans; } \\
\text { - development of regulatory documents and system of employee } \\
\text { incentives }\end{array}$ \\
\hline $\begin{array}{l}\text { Budgeting and } \\
\text { accounting for possible } \\
\text { deviations }\end{array}$ & $\begin{array}{l}\text { developing flexible budgets, taking risks into account based on } \\
\text { predetermined circumstances and situational budgeting }\end{array}$ \\
\hline
\end{tabular}

If the strategic development plan of the farm provides for a threefold increase in sales in three years, it is necessary to prepare a list of measures necessary to implement the approved strategic plan for sales in the next year. If a farmer has set a $14-15 \%$ increase in revenue in his annual product sales plan, it is clear that he will not be able to achieve his strategic goal after three years. The main objectives of financial and economic activities, ie the ability to maximize the benefits of the farmer, the optimization of the capital structure, ensuring its financial stability, the definition of financing strategies are also defined in this way.

A skilled and well-developed marketing strategy is also an important factor in shaping the financial budget of farms. This is especially important for medium and small farms specializing in fruit and vegetable growing, as they are quickly affected by sales volumes, 
changes in income levels, and their financial condition depends on whether there is a market demand for the products (works, services) sold.

The main goals and objectives of the farm for the next period are determined in accordance with the strategic development plan, the relationship between financial and production (marketing) indicators is determined. Goals should be clear and expressed in quantitative and qualitative terms for subsequent evaluation of the results achieved.

At the same time, it is necessary to clarify the main terms used in the budgeting of farms. In particular, it is necessary to define the content of such concepts as "income", "expenditure", "revenue", "cash flow", "payments" and ensure that they are interpreted in the same sense in the budgeting process.

Thus, it is expedient to develop and implement a system of budgeting on farms in the following sequence:

- analysis of the current financial situation and economic processes, identification of responsibility centers, budgeting and timing of reporting;

- formation of the budget model (number of budgets) and structure of budgets and definition of connections between them;

- Forming the general budget of the farm in conjunction with strategic goals;

- accounting, control of economic transactions in the activities of the farm and comparison of planned indicators with actual indicators;

- Formation of periodic (monthly, quarterly) internal management reports, analysis of deviations, identification of reasons and, if necessary, adjustments to the budgets for future periods;

- Development and formalization of a system of documents regulating the budgeting process and standards for staff incentives.

It is recommended to form the system of financial budgeting on farms in the following stages (Table 3).

Table 3. Stages of formation of the financial budgeting system.

\begin{tabular}{|c|c|}
\hline Stages & Clarification \\
\hline $\begin{array}{l}\text { 1. Stage of study and } \\
\text { organizational- } \\
\text { methodological preparation } \\
\text { of the processes of financial } \\
\text { and economic activity of the } \\
\text { farm }\end{array}$ & $\begin{array}{l}\text { - analysis of the financial condition of the farm; } \\
\text { - analysis of the state of financial planning; } \\
\text { - studying the features and organizational structure of the farm; } \\
\text { - determining the centers of responsibility and timing of budgeting; } \\
\text {-identification of the main, including financial goals and objectives } \\
\text { of the farm; }\end{array}$ \\
\hline $\begin{array}{l}\text { 2. Formulation of basic } \\
\text { operating budgets and } \\
\text { ensuring the connection } \\
\text { (dependence) between them }\end{array}$ & $\begin{array}{l}\text { - preparation of operational and basic budgets; } \\
\text { - structure of budgets, the relationship between them and the } \\
\text { sequence of their formation. }\end{array}$ \\
\hline $\begin{array}{l}\text { 3. Formation, definition } \\
\text { and preparation of the } \\
\text { general budget of financial } \\
\text { budgets }\end{array}$ & $\begin{array}{l}\text { - preparation of financial budgets; } \\
\text { - making and clarifying amendments to budgets; } \\
\text { - Providing the budget to the farmer; } \\
\text { - approval of the financial budget }\end{array}$ \\
\hline $\begin{array}{l}\text { 4. Accounting and control } \\
\text { of business transactions }\end{array}$ & $\begin{array}{c}\text { - execution of budgets and accounting of actual data; } \\
\text { - control over budget execution }\end{array}$ \\
\hline
\end{tabular}




\begin{tabular}{|c|c|}
\hline $\begin{array}{c}\text { 5. Formulation of reports } \\
\text { and analysis of budget } \\
\text { execution }\end{array}$ & $\begin{array}{c}\text {-analysis of budget execution, amendments to the budgets of } \\
\text { subsequent periods (if necessary) }\end{array}$ \\
\hline $\begin{array}{c}\text { 6. Development of } \\
\text { documents regulating the } \\
\text { budgeting process }\end{array}$ & $\begin{array}{c}\text { - budgeting regulations, Regulations on budgeting, job descriptions } \\
\text { - development of the Regulation on awards and other internal } \\
\text { regulatory documents. }\end{array}$ \\
\hline
\end{tabular}

The formation of the financial budgeting system at these stages has a recommendatory character and consists of a methodology for developing and implementing a budgeting system that includes the sectoral characteristics of farms and the specifics of financial management.

In addition to the farmer himself, farms must have a manager or accountant responsible for the results of financial and economic activities. It is important to identify the causes of unsatisfactory organization of financial budgeting on the farm, to identify shortcomings, as well as to identify new goals and aspirations and needs of the farm. Financial plans and budgets are closely interrelated, and the initial parameters of one budget are the initial data for other budgets. The structure of the budget model can be in the same pattern for farms of the same size and specialization. But it is different for large farms with their own infrastructure. For example, the budget model for farms in the agricultural and livestock sector will not have a budget for commercial expenditures, a budget for management expenditures, and a number of other similar budgets. The budget model of processing, various service farms can include the production budget, the budget for the purchase of raw materials and supplies, as well as the budget model of large manufacturing enterprises. The difference between the budget models of such farms is that budgeting in the service sector often has to be done on a project-by-project basis, and it is necessary to formulate specific budgets for each project. The budget model is also influenced by the size of the farm. Summarizing the above considerations, we present the model budget models for farms in different sectors and areas of activity (Table 4).

It is not always advisable to develop all types of budgets when drawing up budgets and plans on farms, and in many cases it makes no sense to divide them into smaller budgets and plans. In some cases, it is more effective to create general plans without components or in combination. For example, for a large farm engaged in farming, horticulture and viticulture, budgets can be formed for certain types of production. For example, the budget for the production of raw cotton, the budget for the cultivation of wheat and other cereals, the budget for milk production and processing, and so on.

When developing a budget model, it is necessary to take into account not only the types of budgets, but also their structure (budget-forming items, budget classification), the interrelationships between budgets, as well as the sequence of their formation.

It is also important to determine what kind of information the farmer wants to receive and in what form. If the budget includes planned cost items that generate variable costs, and the full cost is generated in the accounting account, or vice versa, this will be a serious obstacle to comparing the planned figures with actual figures and analysis in general. In this case, a single form should be developed to ensure that the plan indicators are comparable to the calculated indicators. This work is done by developing a separate accounting policy for management accounting purposes. Such accounting policies should reflect the main objectives of budgeting, accounting, control, cost and performance analysis. It is necessary to ensure the compatibility of items in the system of management accounting and items in the system of budgets. If in the production budget seeds and planting material are allocated by a separate item, the management accounting system should also establish accounts that 
summarize information on the cost of seeds and planting material. It is also advisable to open analytical accounts for seed varieties of agricultural crops.

Table 4. Budgeting model for farms operating in different sectors.

\begin{tabular}{|c|c|}
\hline Sectors & Budgeting model \\
\hline Crop production & $\begin{array}{l}\text { Operating budgets: sales budget; production budget; production inventory } \\
\text { budget; procurement budget (budget for the use of materials or direct costs for } \\
\text { materials); general production budget; labor cost budget; } \\
\text { Operating budgets can also include a credit plan, tax budget, and more. } \\
\text { Basic budgets: investment activity budget; income and expenditure budget; } \\
\text { cash flow budget; balance forecast. }\end{array}$ \\
\hline Cattle husbandry & $\begin{array}{l}\text { Operating budgets: sales budget; procurement budget; trade balance; period } \\
\text { expenditure budget; credit plan. } \\
\text { Basic budgets: revenue and expenditure budget; cash flow budget; balance } \\
\text { forecast. }\end{array}$ \\
\hline $\begin{array}{c}\text { Processing of } \\
\text { agricultural products } \\
\text { and services }\end{array}$ & $\begin{array}{l}\text { Operating budgets: sales budget; procurement budget; labor costs; period } \\
\text { expenditure budget, etc. } \\
\text { Basic budgets: revenue and expenditure budget; cash flow budget; balance } \\
\text { forecast. }\end{array}$ \\
\hline
\end{tabular}

The formation of a budget model in a farm should begin with the calculation of the most important indicators that determine the results of its activities. Such indicators include: demand for the product, production capacity, availability of labor resources, access to raw materials and supplies. As farmers gain experience in developing and implementing budgets, they can become more aware of the form, structure, and interrelationships between budgets that best meet the needs of the farm.

One of the key issues is the preparation, amendment and clarification of financial budgets, as well as the development of the general budget. Once the financial structure of the farm and the budget model are formed, the general budget of the farm is developed in conjunction with strategic goals. This process includes (Fig. 2):

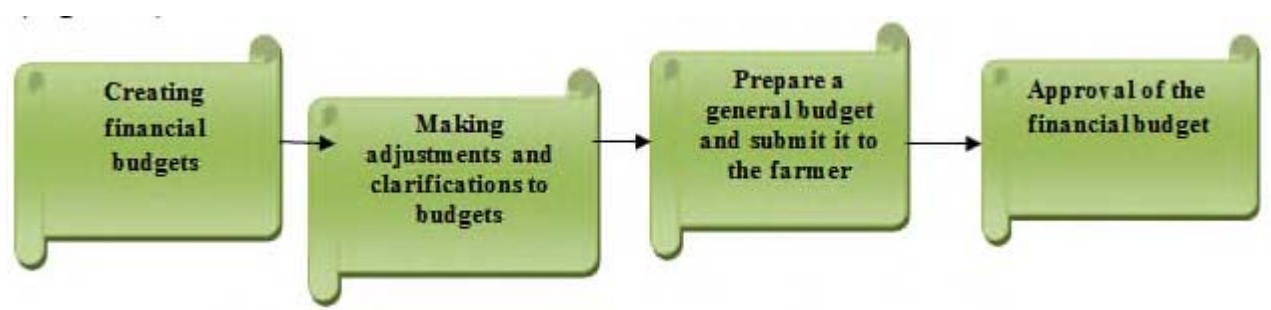

Fig. 2. Stages of development of financial budgets.

Annual financial budgets are formed taking into account the impact of last year's factors on the size of the plan. Farms can also create year-round budgets if necessary, for example, from April to August (sowing, care, vegetation, etc.) or from September to December (cotton harvest, winter wheat planting, autumn plowing, saline washing, etc.).

Budgets and plans are determined on a monthly and quarterly basis, with plan performance also checked against high-level budgets. Several options for farm development 
forecasts will be considered based on the study of different conditions and the application of the situational planning method.

The general budget is then drawn up and discussed. On farms, it is often necessary for the farmer to be personally involved in the process of formulating plans and budgets, especially strategic plans and budgets. Therefore, this stage is applied in enterprises where more budgeting tasks are clearly limited and referred to a special department. However, it is advisable for large specialized farms to apply this step in practice. In this case, the process of sales, costs, etc. to assess the effectiveness of the work of the centers of responsibility of the farmer. defines the main goals and indicators. Budgets are then drawn up taking into account his or her views, and then the plans and draft budgets are discussed with the farmer to make sure they reflect fair and expected performance standards, and adjustments are made as necessary. When approving budget indicators, it is necessary to assess the validity of planned expenditures and payments, as well as the validity of revenues and revenues.

Finally, financial budgets should be discussed with the farmer and approved and monitored, taking into account the outcome of the agreement.

\section{Conclusions}

In summary, a well-developed methodology for the formation and execution of financial budgets on farms as a means of management accounting allows forecasting income and expenses and financial results of the farm, setting targets for financial efficiency and ensuring financial stability.

\section{References}

1. D. N. Saidova, SH. S. Dehkanova, South Asian Journal of Marketing \& Management, 9(8), 47-54 (2019)

2. Z. Abidin, N. M. Kamal, K. Jusoff, International Journal of Economics and Finance, 1(1), 150-161 (2014)

3. M. Afanasyev, L. Myasnikova, Economy questions, 4, 75-86 (2005)

4. U. Mukhtorov, In E3S Web of Conferences, 244, 03013 (2021)

5. B. E. Needles, M. Powers, S. K. Mills, H. R. Anderson, Managerial accounting, 425 (2012)

6. A. Pardayev, Z. Pardayeva, Managerial accounting, 318 (2014) (in Uzbek)

7. B. Khasanov, A. Khashimov, Managerial accounting, 312 (2013)

8. A. Avlokulov, J. Economics and Innovative Technologies, 3, 121-125 (2017)

9. M. Bukhalkov, Accounting, 254 (2000) (in Russian)

10. M. V. Nikolaev, I. E. Egorova, Problems of the modern economy, 3/4(19/20), 117-128 (2006) 